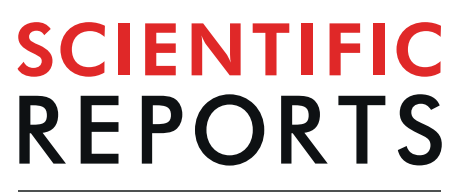

\title{
OPEN Mint companion plants enhance the attraction of the generalist predator Nesidiocoris tenuis according to its experiences of conspecific mint volatiles
}

\begin{abstract}
Hojun Rim, Sayaka Hattori \& Gen-ichiro Arimura*
Mint plants enable improvement of pest management by attracting herbivore enemies to constitutively released mint volatiles. The generalist predator Nesidiocoris tenuis is used worldwide to control agricultural pests, but little is known about whether mint can serve as a companion plant that attracts this predator. To examine this, olfactory responses of $N$. tenuis were assessed using apple mint, candy mint, and spearmint as odor sources. Of the volatiles released by these mint species, candy mint volatiles alone were more attractive than those from undamaged eggplant, and were as attractive as volatiles from eggplant damaged with Spodoptera litura larvae. However, no prominent preference for particular volatile(s) among the mint volatiles was shown by $O$. strigicollis. When $N$. tenuis had been previously exposed to candy mint, the predator showed a stronger preference for candy mint volatiles than damaged eggplant volatiles. It was, however, irrelevant whether the predator received benefit or not by predating animal prey during the mint-experience period. In contrast, spearmint-experience increased the preference for spearmint volatiles only when the predator acquired prey during the mintexperience period. These findings suggest that previous exposure of $N$. tenuis to some particular mint species can increase its preference for volatiles from the conspecific mints.
\end{abstract}

Plants produce and emit volatile organic chemicals (VOCs) in order to resist environment stresses such as heat and light ${ }^{1}$, to deter herbivores and pathogenesis ${ }^{2-4}$, and to attract beneficial organisms, including natural enemies of herbivores $^{5-7}$ and pollinators ${ }^{8}$. The pivotal roles of plant VOCs in the tritrophic system consisting of plant, herbivore, and predator have been intensively researched in a large array of cultivated crops ${ }^{7}$ to be applied for use of biological control of herbivores ${ }^{9}$. Among such applications, "companion planting” is one successful example of polyculture in which target plants (TPs) are cultivated with companion plants (CPs) to assist TP growth or protection against pests by attracting beneficial insects or repelling pests ${ }^{10}$. For example, CPs such as mint, basil and marigold work as attractants for herbivore enemies ${ }^{11,12}$. Moreover, an aphid predator, Cycloneda sanguinea L. (Coccinellidae), has been shown to be attracted to corianders owing to their pollen and nectar serving as supplementary foods ${ }^{13}$.

Recently, Togashi et al. showed that candy mint (Mentha x piperita L. cv. Candy) and spearmint (M. spicata L.) attract Phytoseiulus persimilis Athias-Henriot (Phytoseiidae), a specialized predatory mite of Tetranychidae, but not Neoseiulus californicus McGregor (Phytoseiidae) ${ }^{14}$, a generalized predator that consumes not only mites but also pollen, thrips, and other tiny arthropods ${ }^{15}$. These results were certainly unexpected because it was initially expected that the generalist $N$. californicus rather than the specialist $P$. persimilis would be responsive to mint VOCs. To the best of our knowledge about companion plants attracting generalist predators, the only other publications are reports showing that basil plants are able to attract the generalist predator green lacewing, Ceraeochrysa cubana Hagen (Chrysopidae ${ }^{16}$, but not another generalist predatory mirid bug, Macrolophus pygmaeus Rambur (Miridae) ${ }^{17}$. 


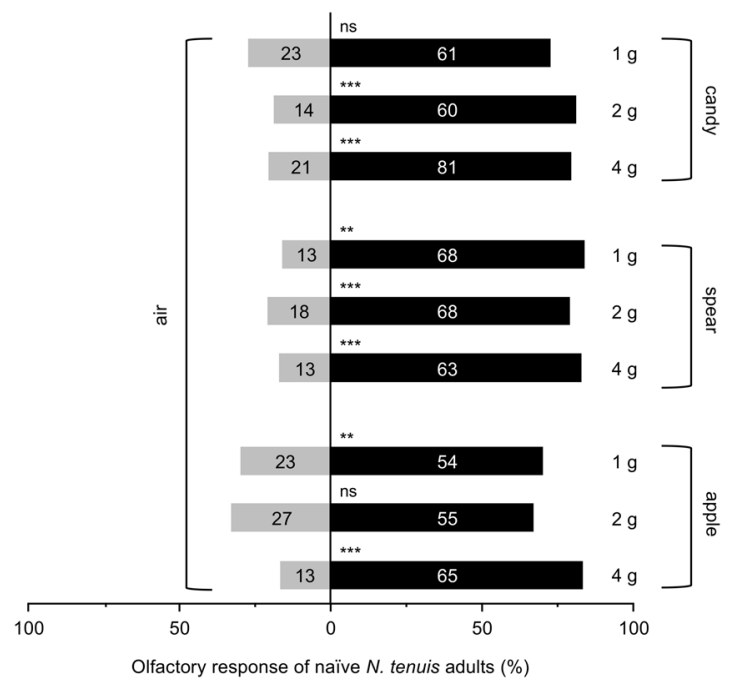

Figure 1. Olfactory response of naïve adults of Nesidiocoris tenuis to VOCs from candy mint, spearmint or apple mint plantlets (1,2 or 4 gram fresh weight) vs. clean air in a Y-tube olfactometer. The numbers within the bars represent the numbers of $N$. tenuis adults that made a choice. Asterisks indicate significant differences based on a generalized linear mixed model (GLMM) with a Wald test $(* * * P<0.001 ; * * 0.001 \leq P<0.01$; ns, $P \geq 0.05)$.

In order to further our understanding of generalist predator attraction to CPs, in the current study we assessed the preference of two generalist predators, Nesidiocoris tenuis Reuter (Miridae) and Orius strigicollis Poppius (Anthocoridae), for mint VOCs using a Y-tube olfactometer assay. These insects are generalists and omnivores which can utilize both diverse animal and plant species as their diets. $N$. tenuis preys on whitefly, thrips, mites, aphids, and eggs/young larvae of lepidopterans ${ }^{18-22}$. O. strigicollis is a biocontrol agent for small agricultural pests, including mites, aphids, thrips, eggs or young Lepidopteran larvae ${ }^{23}$. Both predators have been successfully developed for biological control in a suite of agricultural systems ${ }^{24-28}$.

Based on previous findings by Togashi et al. ${ }^{14}$, we focused on candy mint (M. x piperita L. cv. Candy), spearmint (M. spicata L.), and apple mint (M. suaveolens Ehrh.) as CPs, whose VOCs have been categorized into three distinct types, namely, cool-pungent, cool-sweet, and cool-fruity, respectively ${ }^{29}$. In addition, in this study we explored the importance of plastic experiences of exposure to mint odors on predators' attractivity, because we are aware that olfactory preference of herbivores' natural enemies can be elevated through associative experiences $^{30}$. The natural enemies come to prefer VOCs released from the herbivore-infested host plant in some cases when they have previously experienced the conspecific herbivore prey on the conspecific host species with the same genotype ${ }^{31,32}$. For instance, it has been shown that $N$. tenuis adults prefer VOCs from eggplants more strongly when they have experienced those VOCs while having their favorite animal prey on eggplant for 4 days ${ }^{31}$. However, $N$. tenuis adults do not show such a VOC preference when they have not had such experience.

Here, we present findings showing the importance of the plastic experience of mint VOCs on the attractivity of $N$. tenuis. Finally, our findings suggest a potential application of mints for pest control that is boosted by the plastic experiences of the carnivore.

\section{Results}

Attractiveness of mint plant VOCs to $\mathbf{N}$. tenuis and $\mathbf{O}$. strigicollis. Naïve adults of $N$. tenuis tested in Y-tube olfactometer assays preferred VOCs released from candy mint, spearmint and apple mint $(1,2$ or 4 grams fresh weight (gFW) ) when compared with clean air $(P<0.05$, except in the cases of $1 \mathrm{gFW}$ of candy mint $[Z=1.934, P=0.053]$ and 2 gFW of apple mint $[Z=1.816, P=0.069]$ ) (Fig. 1). Based on these predator responses, we focused on VOCs from $4 \mathrm{gFW}$ mints for use in subsequent assays.

$N$. tenuis adults preferred VOCs from $4 \mathrm{gFW}$ of candy mint over those from undamaged eggplant $(Z=3.292$, $P<0.001)$ (Fig. 2). However, they were not significantly attracted to VOCs from spearmint or apple mint over VOCs from undamaged eggplant $(Z=1.497, P=0.134$ for spearmint; $Z=0.972, P=0.331$ for apple mint) (Fig. 2).

Another generalist predator, Orius strigicollis, was not attracted to mint VOCs in comparison to undamaged or damaged eggplant VOCs, although it preferred VOCs released from $4 \mathrm{gFW}$ of candy mint, spearmint and apple mint when compared with clean air $(Z=2.584, P=0.009$ for candy mint; $Z=2.214, P=0.027$ for spearmint; $Z=3.165, P=0.002$ for apple mint) (Fig. 3). We therefore did not focus on $O$. strigicollis for the subsequent assays.

Previous experiences of $\boldsymbol{N}$. tenuis affect its preference for candy mint VOCs. Naïve adults of $N$. tenuis were equally attracted to VOCs from candy mint and to those from eggplant damaged by $S$. litura larvae for 1 day $(Z=1.409, P=0.159)$ (Fig. 4a). The attractivity of candy mint VOCs was increased when $N$. tenuis had been previously exposed to candy mint plantlets for 3 days: in this case, the predator preferred candy mint VOCs over VOCs from the damaged eggplant $(Z=3.154, P=0.0016)$ (Fig. $4 \mathrm{a})$. The same held true for $N$. tenuis that had been exposed to candy mint plantlets while being provided with animal prey (E. kuehniella eggs) $(Z=4.684, P<0.001)$ (Fig. 4a), indicating that exposure to candy mint simultaneously with either beneficial (with-diet) or unbeneficial 


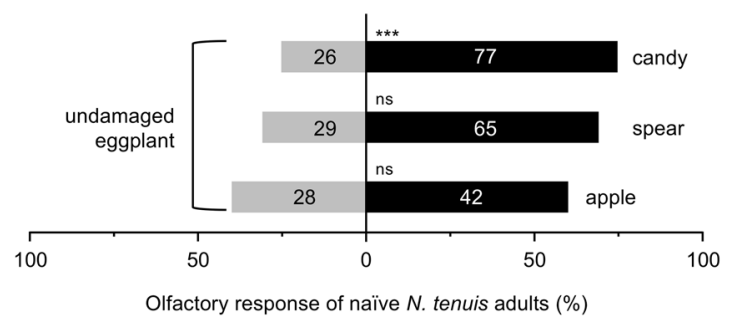

Figure 2. Olfactory response of naïve adults of Nesidiocoris tenuis to VOCs from candy mint, spearmint or apple mint plantlets ( $4 \mathrm{~g}$ fresh weight) vs. those from undamaged eggplant in a Y-tube olfactometer. The numbers within the bars represent the numbers of $N$. tenuis adults that made a choice. Asterisks indicate significant differences based on a generalized linear mixed model (GLMM) with a Wald test $(* * * P<0.001 ; \mathrm{ns}$, $P \geq 0.05)$.

(a) mint plants vs. air

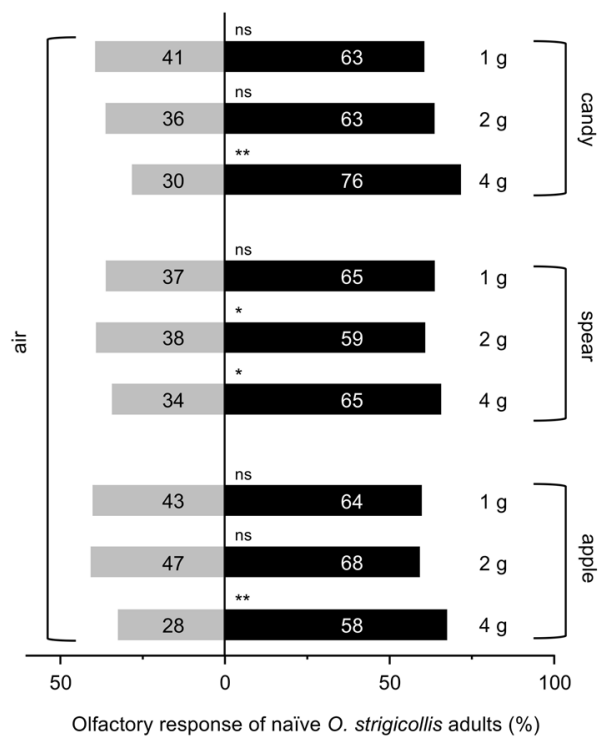

(b) mint plants vs. undamaged eggplant

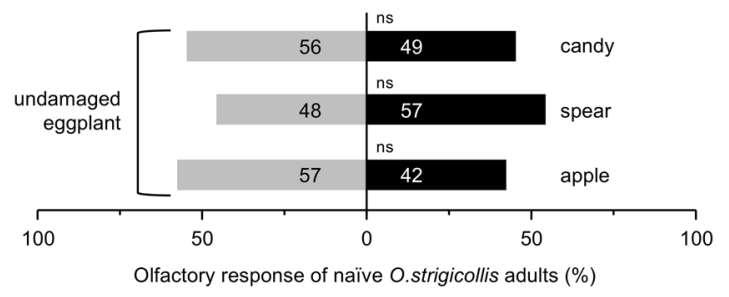

(c) mint plants vs. damaged eggplant

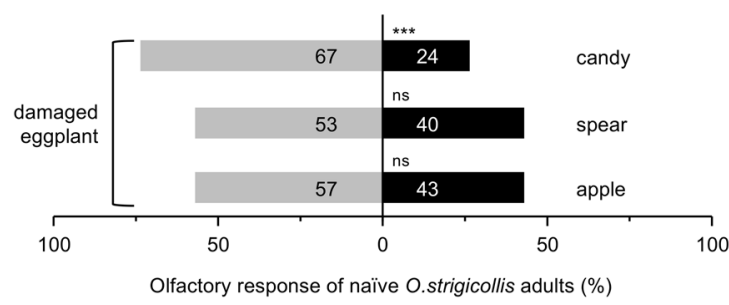

Figure 3. Olfactory response of naïve adults of Orius strigicollis to VOCs from candy mint, spearmint or apple mint plantlets (1, 2 or 4 grams fresh weight) vs. clean air (a), VOCs from mint plantlets (4 grams fresh weight) vs. those from undamaged eggplants (b) or VOCs from mint plantlets (4 grams fresh weight) vs. those from damaged eggplants (c) in a Y-tube olfactometer. The numbers within the bars represent the numbers of $O$. strigicollis adults which made a choice. Asterisks indicate significant differences based on a Generalized linear mixed model (GLMM) with a Wald test $(* * * P<0.001$; $* * 0.001 \leq P<0.01 ; * 0.01 \leq P<0.05$; ns, $P \geq 0.05)$.

(without-diet) experiences was able to increase the preference of the predator for mint VOCs $\left(x^{2}=14.953, d f=1\right.$, $P<0.001$ and $x^{2}=6.836, d f=1, P=0.009$, respectively).

Next, in order to examine whether the increased preference was due to the experience of perceiving mint VOCs or whether it was due to other factors such as the physical experience of staying on a mint plant irrespective of mint VOCs, we assessed the performance of $N$. tenuis that had been previously exposed to VOCs from candy mint plantlets covered with mesh. This exposure increased the predators' olfactory preference for candy mint VOCs $\left(x^{2}=7.619, d f=1, P=0.006 ; Z=4.208, P<0.001\right)$ (Fig. $\left.4 \mathrm{a}\right)$, confirming that mint VOCs served as primary factors that confer the significant subsequent preference of the predator for these VOCs.

Finally, to explore the specificity of the VOC composition for this plasticity effect, we assessed the olfactory response of $N$. tenuis after $N$. tenuis had experienced VOCs from spearmint plantlets covered with mesh while having animal prey or not. The VOC blend of candy mint is qualitatively different from that of spearmint ${ }^{14}$. The assays showed that the spearmint VOC-experience affected none of the responses of $N$. tenuis to candy mint VOCs $\left(x^{2}=0.047, d f=1, P=0.828 ; Z=1.305, P=0.192\right)$ (Fig. $\left.4 a\right)$, indicating the specificity of the mint VOC composition on the experience trait. Similarly, when $N$. tenuis had experienced exposure to spearmint plantlets while having prey, it did not show a preference for candy mint VOCs over damaged eggplant VOCs $\left(x^{2}=0.042\right.$, $d f=1, P=0.838 ; Z=0.960, P=0.337$ (Fig. 4 a).

Do mintVOC experiences of $N$. tenuis affect its preferences toward spearmint and apple mint VOCs? The naïve adults of $N$. tenuis were not attracted to either spearmint or apple mint VOCs in comparison to damaged 

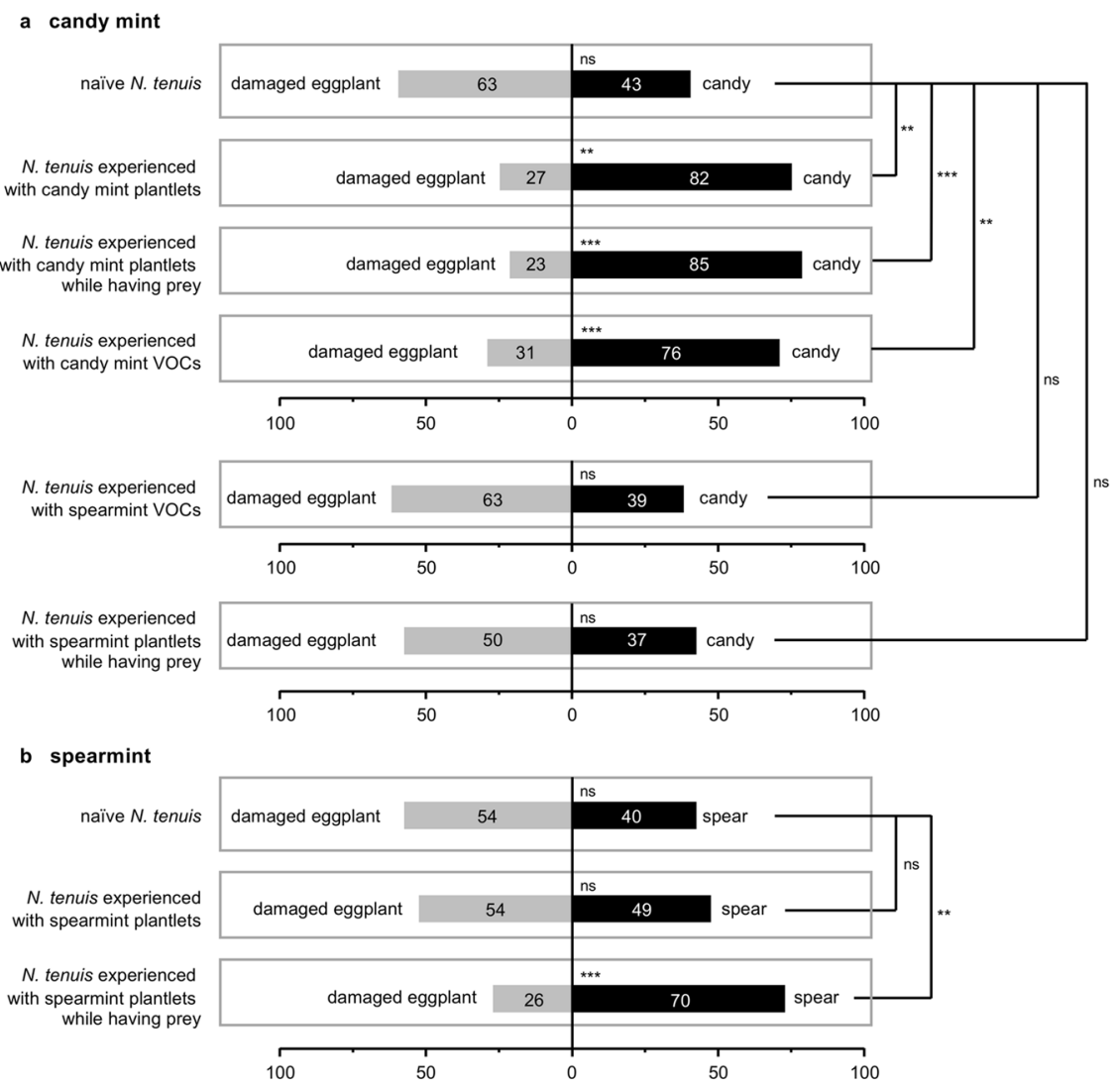

c apple mint

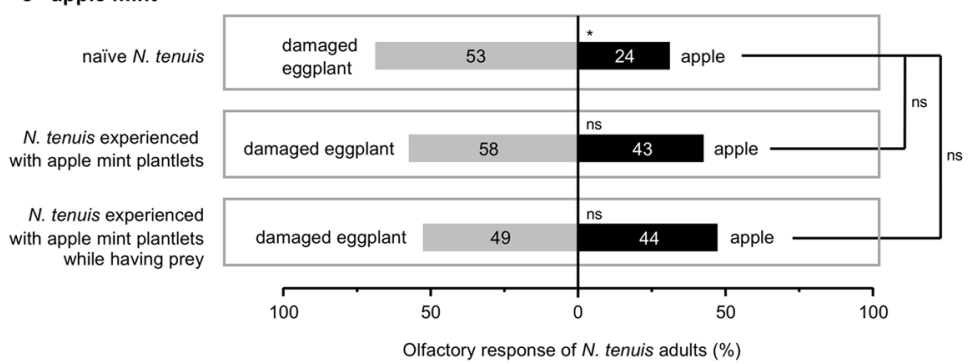

Figure 4. Olfactory response of Nesidiocoris tenuis adults to VOCs from candy mint (a), spearmint (b), or apple mint (c) vs. those from eggplant damaged with Spodoptea litura larvae for $24 \mathrm{~h}$. We used $N$. tenuis that was naïve to the respective target of mint sp. or $N$. tenuis that had been exposed to the same or different species of mint plantlets or mint VOCs while being provided with animal prey or not. The numbers within the bars represent the numbers of $N$. tenuis adults that made a choice. Asterisks indicate significant differences between left and right columns. The effects of experiences were analyzed based on the generalized linear mixed model (GLMM) with a Wald test $(* * * P<0.001 ; * * 0.001 \leq P<0.01 ; * 0.01 \leq P<0.05$; ns, $P \geq 0.05)$.

eggplant VOCs $(Z=1.226, P=0.220$ and $Z=2.018, P=0.044$, respectively) (Figs. $4 \mathrm{~b}$ and $4 \mathrm{c}$ ). In contrast to the increase of the preference caused by experience with candy mint plantlets or candy mint VOCs (see Fig. $4 \mathrm{a}$ ), previous exposure to spearmint plantlets did not result in an increased preference for spearmint VOCs $\left(x^{2}=0.358\right.$, $d f=1, P=0.550$ ) (Fig. 4 b). However, when the predators were fed animal prey during spearmint-exposure, they started to prefer spearmint VOCs compared to damaged eggplant VOCs $\left(x^{2}=9.229, d f=1, P=0.002 ; Z=3.802\right.$, $P<0.001$ ) (Fig. 4b). In contrast to the effects of experience with candy mint plantlets, previous exposure to apple mint plantlets did not confer a subsequent preference for apple mint VOCs on $N$. tenuis, regardless of whether $N$. tenuis experienced apple mint-exposure while having or not having animal prey $(Z=0.518, P=0.604$ and $Z=0.643, P=0.520$, respectively) (Fig. 4 c).

The Y-tube olfactometer assay testing $N$. tenuis that had experienced spearmint plantlets while not having consumed animal prey for 3 days and was then supplied with prey for 4 hours immediately before the start of the assays showed no preference of the predator between damaged eggplant VOCs and spearmint VOCs (Supplemental Fig. 1). Thus, we confirmed that the differences between the olfactory responses of the two groups (experienced with mint while having or not having animal prey during this mint-exposure period) were not likely to have been due to whether or not the $N$. tenuis had been starved. 
(a)

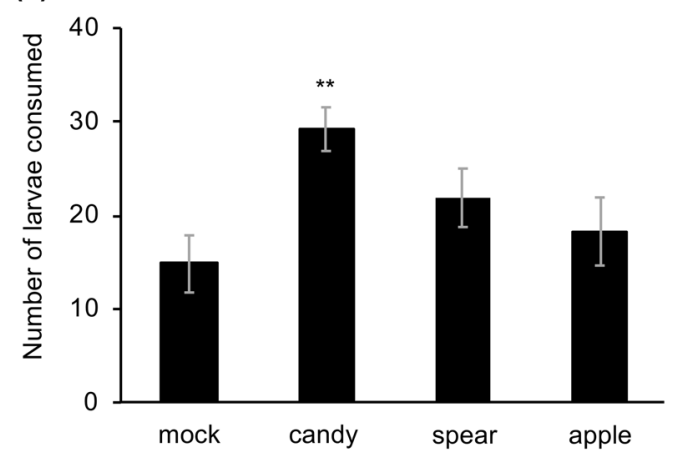

(b)

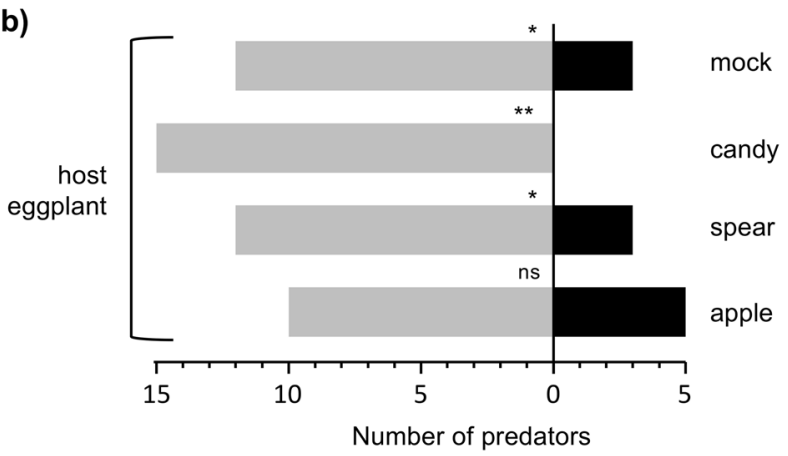

Figure 5. Predation and host-location activity of Nesidiocoris tenuis. The number of Spodoptea litura larvae consumed (a) and localization of predators (b) on either a potted host eggplant or each of neighboring candy mint, spearmint, apple mint or mock (undamaged eggplant) plantlets were evaluated $24 \mathrm{~h}$ after the beginning of assays. Fifteen replicates were performed. For (a), data represent the means and standard errors, and data marked with an asterisk are significantly different from those of mock plantlets, based on one-way ANOVA with post hoc Dunnett's test $(* * 0.001 \leq P<0.01)$. For $(\mathbf{b})$, asterisks indicate significant differences based on a generalized linear model (GLM) with a Wald test (***P<0.001; ns, $P \geq 0.05)$.

Predation activity of $\boldsymbol{N}$. tenuis on the host eggplant in the presence of mint. Finally, we evaluated the total number of $S$. litura larvae consumed by naïve adult females of $N$. tenuis on the host eggplant in the presence or absence of candy mint, spearmint or apple mint plantlets or mock plantlets (eggplant) for $24 \mathrm{~h}$. $N$. tenuis predated the larvae the most voraciously when candy mint was placed proximately $(P=0.005)$ (Fig. 5a). We also found that significantly more predators observed were located on the host eggplant with $S$. litura larvae, not on candy mint/spearmint or undamaged eggplant (mock) (Fig. 5b). However, when apple mint was placed proximately to the host eggplant, the proportion of the predator population that was located on apple mint was similar to that on located the host eggplant $(P=0.206)$ (Fig. $5 b)$.

\section{Discussion}

Previously, candy mint and spearmint have been shown to act as companion plants for crop target plants in a tri-trophic context, by attracting naïve adults of $P$. persimilis, a predator of $T$. urticae ${ }^{14}$. Of great interest is the fact that this attractivity was comparable to that of VOCs released from T. urticae-infested plants.

Here, we showed that naïve adults of the predator N. tenuis were attracted to candy mint VOCs with an activity comparable to that of VOCs from $S$. litura-damaged eggplant and higher than that of undamaged eggplant VOCs (Figs. 2 and 4a). We are aware that undamaged eggplants emit very low levels of VOCs consisting of eight major compounds, while damaged eggplants emit much larger quantities and higher quality of VOCs consisting of at least 21 compounds, leading to a stronger attraction of $N$. tenuis and O. strigicollis towards VOCs from damaged eggplants over those from undamaged eggplant ${ }^{33}$ (unpublished results about O. strigicollis response; Rim et al.). The question we then asked is how those predators prefer mint VOCs. This phenomenon is not surprising because there are some reports similarly showing that predators tend to prefer aromatic volatiles released from French marigold, basil, and coriander plants ${ }^{13,16,34}$, although their mechanisms remain to be understood. However, CP-VOCs are not always preferred by predators, as shown here by the lack of any strong preference by O. strigicollis (Fig. 3). One of the interesting aspects of predator responses to CP-VOCs is the variability and plasticity shown by predators.

The highlight of the current research was the finding that $N$. tenuis adults showed increased preference for mint VOCs when they had previously experienced the identical mint VOCs (Fig. 4). More importantly, it should be emphasized that the attractiveness of candy mint VOCs to $N$. tenuis adults was elevated when the N. tenuis had previously experienced the identical mint VOCs even without having been rewarded by prey or other beneficial 
supplies (Fig. 4a). To the best of our knowledge, this is the first example of a positive impact of unbeneficial experiences on subsequent responses of a herbivore enemy.

Unbeneficial experiences frequently do not affect or negatively affect a predator's subsequent performance. For instance, $N$. tenuis adults scarcely preferred VOCs from damaged eggplant if they had not previously experienced the VOCs from eggplant with a reward of prey ${ }^{31}$, which is in agreement with our data for the case of spearmint-experience (Fig. 4b). Moreover, P. persimilis and Anthocoris nemoralis have been reported to be repelled by herbivore prey-induced plant VOCs after they experienced the identical VOCs without any prey-supply ${ }^{35,36}$. Therefore, we considered the possibility that $N$. tenuis may be rewarded by using candy mint plants as hosts, owing to their nutritional and water resources. However, here we showed that exposure of $N$. tenuis to candy mint VOCs without their being hosted directly on candy mint plants, and without any prey-supply, caused an increase of the preference of $N$. tenuis for candy mint VOCs. This suggests that exposure of $N$. tenuis to the unique blend of candy mint VOCs primes the preference of the predator for the identical mint VOCs, regardless of the fact that mint plants themselves are beneficial for the insect.

Moreover, the plastic learning of the candy mint VOC composition by N. tenuis must be accurate, as shown by our finding that previous exposure to spearmint VOCs did not prime an increased preference for candy mint VOCs (Fig. 4a). As described above, candy mint VOCs, consisting mainly of menthone, menthofuran and menthol, are totally different from spearmint VOCs, consisting mainly of carvone ${ }^{14}$. Such qualitatively different VOC compositions are likely the cause of the different abilities to prime the preference of $N$. tenuis. However, it remains to be determined which candy mint $\mathrm{VOC}(\mathrm{s})$ are responsible for $N$. tenuis's learning. Alternatively, the composite blend of candy mint VOCs may be responsible for it.

Notably, candy mint VOCs were also found to stimulate the consumption of prey by N. tenuis (Fig. 5a). Although we were initially concerned about the possible trapping of $N$. tenuis on mint plants, which might interfere with hosting of $N$. tenuis on the host eggplant, this did not occur, as shown by the findings with candy mint and spearmint (Fig. 5b). All these results strongly support the possibility that mint CPs act as attractant cues but not hosting cues. In addition, candy mint VOCs work as an appetite-promoting cue as well.

\section{Conclusions}

Competing theories of volatile attraction and volatile masking in particular have been suggested to explain responses in the presence of volatiles from multiple plant sources in tritrophic interaction $s^{37,38}$. The findings of this study provide a good framework, but the results presented hint that predator responses are neither as predictable nor rigid as other studies have suggested. This report therefore has value both as a specific test of the value of CPs and also as a more basic exploration of the effects of nearby plants on predator responses to host VOCs.

Moreover, the findings of our study provide novel insights into potential application methods using candy mint and spearmint as CPs for pest management in agriculture and horticulture. These CPs are expected to provide powerful applications when mint VOC-experienced $N$. tenuis predators are simultaneously released in the field. However, it remains to be explored whether mint plants in field or greenhouse settings would increase predation or whether they would mask herbivore location. Nonetheless, given the fact that aromatic plants, including mint (M. canadensis and M. haplocalyx), basil, and marigold, etc., serving as CPs, have been successfully shown to recruit natural enemy arthropods and reduce herbivores in an array of agricultural fields for pear orchards, tomato farms and tea plantations ${ }^{12,39-43}$, it is highly possible that candy mint and spearmint could be likewise applied for pest control against mint-unexperienced and -experienced $N$. tenuis in field agriculture.

Moreover, given the fact that $O$. strigicollis was not responsive to any of the mint species (Fig. 3), as similarly shown for $N$. californicus, a generalist predatory mite ${ }^{14}$, it should be pointed out that mints do not serve as CPs for all predators. Efficient methods for determining which target plants, seasons, and environmental conditions promote pest management will need to be established to enable practical use of mints as CPs for agriculture and horticulture.

\section{Methods}

Plants. All of the plants used were incubated in climate-controlled rooms at $24 \pm 1{ }^{\circ} \mathrm{C}$ with a photoperiod of $16 \mathrm{~h}\left(80 \mu \mathrm{E} \mathrm{m}^{-2} \mathrm{~s}^{-1}\right)$. The light period was from 07:00 to 23:00. Apple mint (M. suaveolens Ehrh.), candy mint (M. x piperita L. cv. Candy), and spearmint (M. spicata L.) were obtained from gardening shops, cultivated after insecticide treatment, and propagated by the stem-cutting method. For use as odor sources, the mint plantlet(s) (approximately 1, 2, or 4 grams fresh weight $[\mathrm{gFW}]$ ) were cut and placed in a glass vial filled with water $(35 \mathrm{~mL})$ according to the method described previously ${ }^{14}$. Given the fact that there was no remarkable difference between the VOC profile of the cut plantlets and that of the intact plants of any of the mint species (see Supplemental Fig. 2), we confirmed that mint VOCs focused on in this study served as constitutive VOCs, not mechanical damage-induced VOCs.

The seeds of eggplant (Solanum melongenas L. cv. Chikuyo, Solanaceae) were planted in soil in plastic pots ( $4.5 \mathrm{~cm}$ in diameter, $5.5 \mathrm{~cm}$ high) and grown for 21-28 days until 4 leaves were fully developed. In order to avoid airborne contamination of eggplants with mint VOCs, all of the eggplants were cultivated at least $5 \mathrm{~m}$ away from mint plants when the plants were cultivated in the same room.

Insects. All of the insects used in the current study were incubated in climate-controlled rooms at $24 \pm 1^{\circ} \mathrm{C}$ with a photoperiod of $16 \mathrm{~h}\left(30 \mu \mathrm{E} \mathrm{m}^{-2} \mathrm{~s}^{-1}\right)$. N. tenuis was obtained from Mitsuki Shimomoto and Kazuhide Nakaishi (Kochi Prefectural Agricultural Technology Research Center, Nangoku, Japan) in 2012. In a lidded plastic container $(12 \mathrm{~cm} \times 17 \mathrm{~cm} \times 5 \mathrm{~cm}$ high, having 5 mesh windows $[1 \times 1 \mathrm{~cm}])$, about 20 insects were reared with supplies of Ephestia kuehniella Zeller (Lepidoptera: Pyralidae) eggs (Agrisect Inc., Inashiki, Japan) as food and Sedum rubrotinctum R.T. Clausen (Crassulaceae) leaves as oviposition substrate and water resource. Twice a week, $N$. tenuis eggs on the $S$. rubrotinctum leaves were transferred to another plastic container that was supplied 
with fresh E. kuehniella eggs and S. rubrotinctum leaves. We used $N$. tenuis adults 5-10 days after emergence for the experiments. In order to avoid associative learning of the odor of mint volatiles by $N$. tenuis during rearing, $N$. tenuis was reared in seclusion from mint plants and with constant ventilation of the incubator room.

Orius strigicollis was purchased from Sumitomo Chemical Co., Ltd. (Tokyo, Japan) in 2011 and reared using the same method as described above for $N$. tenuis.

Spodoptera litura Fabricius (Noctuidae) was transferred to our laboratory in 2014 from a culture reared at Sumika Technoservice Co. Ltd. (Takarazuka, Japan). The larvae were reared on artificial diet (Insecta LF, Nihon Nosan Kogyo Ltd., Tokyo, Japan) in a lidded plastic cup $(\varnothing 10 \mathrm{~cm} \times 6 \mathrm{~cm}$, having 2 mesh windows $[2 \times 2 \mathrm{~cm}])$. When larvae reached the final instar, they were transferred to a larger container $(1.6 \mathrm{~L})$ with a mesh-covered lid. Finally, about 30 pupae of $S$. litura were transferred to a lidded plastic cylinder $(\varnothing 12 \mathrm{~cm} \times 33 \mathrm{~cm})$ and reared until their adult stage. Meanwhile, their oviposition was allowed on a piece of paper that fully covered the inside surface of the cylinder. The eggs and larvae were used for assays or continuous rearing. First-instar S. litura larvae were used for the experiments.

Preparation of mint-experienced $\boldsymbol{N}$. tenuis adults. To prepare $N$. tenuis that had been exposed to mint plants under various different conditions, 30 adult females and 30 adult males were put in a plastic cage $(34 \mathrm{~cm} \times 34 \mathrm{~cm} \times 25.5 \mathrm{~cm})$ where two mint plantlets $(4 \mathrm{gFW}$ each) were placed with a sufficient amount of animal prey (about 3500 E. kuehniella eggs) or without prey for 3 days. For some experiments, to expose $N$. tenuis to mint VOCs without contact with mint plants, the adults were reared in the plastic cage in which two mint plantlets (4 gFW each) covered with mesh were placed with a piece of wet cotton wool for water supply without animal prey for 3 days.

Y-tube olfactometer assays. Plantlet(s) of mint plants in a glass vial were placed in a glass container (2L). A potted eggplant plant (about $4 \mathrm{gFW}$ ) that was either undamaged or had been exposed to 10 first-instar $S$. litura larvae for $24 \mathrm{~h}$ was also placed in a glass container $(2 \mathrm{~L})$. Those plants were used as single-odor sources for Y-tube olfactometer assays. Note that $S$. litura larvae were removed just before the start of assays.

The assays were performed according to the method described previously by Rim et al. ${ }^{33}$. Briefly, one N. tenuis individual was introduced at the starting point $(2 \mathrm{~cm}$ from the downwind end of the main tube) in the Y-tube olfactometer $(3.5 \mathrm{~cm}$ inner diameter, $13 \mathrm{~cm}$ long for the main tube, and $13 \mathrm{~cm}$ long for each branch tube) using an insect aspirator made for handling of these predators. O. strigicollis was introduced on the starting point of a Y-wire set inside the Y-tube using a fine brush. When each predator arrived at the end of either side of the Y-tube, we judged that it made a choice. Predators that did not make a choice within $5 \mathrm{~min}$ ("no choice" subjects) were excluded from the statistical analysis. The orientation of the odor-source containers relative to the olfactometer arms was changed after every five bioassays. Assays using both 20 males and 20 females were separately carried out as a single replicate in a day. Three replicates using independent plants were carried out on different days (i.e., 120 predators in all). The experiments were performed in a climate-controlled room $\left(24 \pm 1^{\circ} \mathrm{C}\right)$.

Predation assay. Fifty larvae of $S$. litura (within the first day after hatching) were released onto a potted host eggplant $(4 \mathrm{gFW})$ in a plastic container $(34 \mathrm{~cm} \times 34 \mathrm{~cm} \times 25.5 \mathrm{~cm}$, with two small mesh windows $[12 \times 18 \mathrm{~cm}]$ and one large mesh window $[34 \times 25.5 \mathrm{~cm}])$. Either a mint plantlet $(4 \mathrm{gFW})$ or a mock plantlet (undamaged eggplant [ 4 gFW]) serving as control was then placed in the container $15 \mathrm{~cm}$ apart from the host eggplant. A single adult female $N$. tenuis was immediately introduced to the central point between the host eggplant and the mint/mock plantlet, and the number of $S$. litura larvae that survived was counted after $24 \mathrm{~h}$. We also observed whether the predator was present on either the host eggplant or mint/mock plantlet. Before assays, all the females were reared with a leaf of $S$. rubrotinctum alone for $48 \mathrm{~h}$. The assays were performed in a climate-controlled room $\left(24 \pm 1{ }^{\circ} \mathrm{C}\right)$ with a photoperiod of $16 \mathrm{~h}\left(80 \mu \mathrm{E} \mathrm{m}^{-2} \mathrm{~s}^{-1}\right)$. Fifteen replicates for each set of assays were performed.

Headspace volatile analysis. VOCs from the potted mint plants and plantlets in a glass vial (4-5 gFW) were collected in a glass container (2 L) using Tenax 60/80 (Gerstel GmbH \& Co. KG, Mülheim an der Ruhr, Germany) for $4 \mathrm{~h}$ and analyzed by gas chromatography-mass spectrometry (GC-MS), according to the method described previously by Togashi et al. ${ }^{14}$.

Statistical analysis. All of the results of Y-tube bioassays related to response of predators were analyzed with a generalized linear mixed model (GLMM) with a binomial distribution and logit link using the lme4 package ${ }^{44}$ in $\mathrm{R}$ version $3.4 .2^{45}$. The independent trails and sex of predators were included in the model as random effects. The effects of experiences were analyzed by comparing the model "without experience" to the model "with experience" using a Wald test.

One-way ANOVA with Dunnett's test was used for the results of predation assays using multcomp package ${ }^{46}$. A $P$ value $<0.05$ was considered statistically significant.

Received: 12 June 2019; Accepted: 19 January 2020;

Published online: 07 February 2020

\section{References}

1. Vickers, C. E., Gershenzon, J., Lerdau, M. T. \& Loreto, F. A unified mechanism of action for volatile isoprenoids in plant abiotic stress. Nat. Chem. Biol. 5, 283, https://doi.org/10.1038/nchembio.158 (2009).

2. Veyrat, N., Robert, C. A. M., Turlings, T. C. J. \& Erb, M. Herbivore intoxication as a potential primary function of an inducible volatile plant signal. J. Ecol. 104, 591-600, https://doi.org/10.1111/1365-2745.12526 (2015).

3. Szendrei, Z. \& Rodriguez-Saona, C. A meta-analysis of insect pest behavioral manipulation with plant volatiles. Entomol. Exp. Appl. 134, 201-210, https://doi.org/10.1111/j.1570-7458.2009.00954.x (2010). 
4. Sobhy, I. S., Bruce, T. J. \& Turlings, T. C. Priming of cowpea volatile emissions with defense inducers enhances the plant's attractiveness to parasitoids when attacked by caterpillars. Pest Manag. Sci. 74, 966-977, https://doi.org/10.1002/ps.4796 (2018)

5. Amo, L., Jansen, J. J., van Dam, N. M., Dicke, M. \& Visser, M. E. Birds exploit herbivore-induced plant volatiles to locate herbivorous prey. Ecol. Lett. 16, 1348-1355, https://doi.org/10.1111/ele.12177 (2013).

6. Aljbory, Z. \& Chen, M.-S. Indirect plant defense against insect herbivores: a review. Insect Sci. 25, 2-23, https://doi.org/10.1111/17447917.12436 (2016).

7. Reddy, G. V. P. In Biocommunication of Plants Vol. 14 Signaling and Communication in Plants (eds Günther Witzany \& František Baluška) Ch. 15, 281-301 (Springer Berlin Heidelberg, 2012).

8. Rosas-Guerrero, V. et al. A quantitative review of pollination syndromes: do floral traits predict effective pollinators? Ecol. Lett. 17, 388-400, https://doi.org/10.1111/ele.12224 (2014).

9. Cortesero, A. M., Stapel, J. O. \& Lewis, W. J. Understanding and manipulating plant attributes to enhance biological control. Biol. Control 17, 35-49, https://doi.org/10.1006/bcon.1999.0777 (2000).

10. Parker, J. E., Snyder, W. E., Hamilton, G. C. \& Rodriguez-Saona, C. In Weed and Pest Control - Conventional and New Challenges (eds. Sonia Soloneski \& Marcelo Larramendy) 1-29 (InTech, 2013).

11. Song, B. et al. Intercropping with aromatic plants decreases herbivore abundance, species richness, and shifts arthropod community trophic structure. Environ. Entomol. 41, 872-879, https://doi.org/10.1603/en12053 (2012).

12. Song, B. et al. Intercropping with aromatic plants hindered the occurrence of Aphis citricola in an apple orchard system by shifting predator-prey abundances. Biocontrol Sci. Technol. 23, 381-395, https://doi.org/10.1080/09583157.2013.763904 (2013).

13. Togni, P. H. B. et al. Mechanisms underlying the innate attraction of an aphidophagous coccinellid to coriander plants: Implications for conservation biological control. Biol. Control 92, 77-84, https://doi.org/10.1016/j.biocontrol.2015.10.002 (2016).

14. Togashi, K. et al. Mint companion plants attract the predatory mite Phytoseiulus persimilis. Sci. Rep. 9, 1704, https://doi.org/10.1038/ s41598-018-38098-x (2019)

15. McMurtry, J. A. \& Croft, B. A. Life-styles of Phytoseiid mites and their roles in biological control. Annu. Rev. Entomol. 42, 291-321, https://doi.org/10.1146/annurev.ento.42.1.291 (1997).

16. Batista, M. C. et al. Basil (Ocimum basilicum L.) attracts and benefits the green lacewing Ceraeochrysa cubana Hagen. Biol. Control 110, 98-106, https://doi.org/10.1016/j.biocontrol.2017.04.013 (2017)

17. Parolin, P., Bresch, C., Poncet, C., Suay-Cortez, R. \& Van Oudenhove, L. Testing basil as banker plant in IPM greenhouse tomato crops. Int. J. Pest Manag. 61, 235-242, https://doi.org/10.1080/09670874.2015.1042414 (2015).

18. Calvo, J., Blockmans, K., Stansly, P. A. \& Urbaneja, A. Predation by Nesidiocoris tenuis on Bemisia tabaci and injury to tomato. BioControl 54, 237-246, https://doi.org/10.1007/s10526-008-9164-y (2009).

19. Sanchez, J. A. Zoophytophagy in the plantbug Nesidiocoris tenuis. Agr. Forest Entomol. 10, 75-80, https://doi.org/10.1111/j.14619563.2007.00357.x (2008)

20. Li, L.-R., Xue, R.-F., Wang, X.-J. \& Zeng, F.-R. Predation of Nesidiocoris tenuis to Trialeurodes vaporariorum and Plutella xylostella. Journal of Agricultural University of Hebei 1, 21 (2008).

21. Torreno, H. S. Predation behavior and efficiency of the bug Cyrtopeltis tenuis (Hemiptera: Miridae), against the cutworm, Spodoptera litura (F). Philipp. Entomol. 9, 426 (1994).

22. Gavkare, O. \& Sharma, P. L. Feeding potential of Nesidiocoris tenuis (Reuter) on the two-spotted spider mite, Tetranychus urticae Koch, under laboratory conditions. J. Agric. Urban Entomol. 32, 50-58, https://doi.org/10.3954/1523-5475-32.1.50 (2016).

23. Hinomoto, N., Muraji, M., Noda, T., Shimizu, T. \& Kawasaki, K. Identification of five Orius species in Japan by multiplex polymerase chain reaction. Biol. Control 31, 276-279, https://doi.org/10.1016/j.biocontrol.2004.07.002 (2004).

24. Yano, E. In Nonpesticide Methods for Controlling Diseases and Insect Pests (ed. Peter A. C. Ooi) (Asian Productivity Organization, 2005).

25. van Lenteren, J. C. The state of commercial augmentative biological control: plenty of natural enemies, but a frustrating lack of uptake. BioControl 57, 1-20, https://doi.org/10.1007/s10526-011-9395-1 (2012).

26. Komi, K. Biological control of pest insects in greenhouses use of natural enemy in Kochi Prefecture. Jpn. J. Pestic. Sci. 41, 69-73, https://doi.org/10.1584/jpestics.W15-49 (2016).

27. Calvo, F. J., Lorente, M. J., Stansly, P. A. \& Belda, J. E. Preplant release of Nesidiocoris tenuis and supplementary tactics for control of Tuta absoluta and Bemisa tabaci in greenhouse tomato. Entomol. Exp. Appl. 143, 111-119, https://doi.org/10.1111/j.1570-7458.2012.01238.x (2012).

28. Urbaneja, A., González-Cabrera, J., Arnó, J. \& Gabarra, R. Prospects for the biological control of Tuta absoluta in tomatoes of the Mediterranean basin. Pest Manag. Sci. 68, 1215-1222, https://doi.org/10.1002/ps.3344 (2012).

29. Oyama-Okubo, N. Analysis and classification of emitted scent compounds in leaves of Mentha cultivars. Bull. Natl. Inst. Flor. Sci. 12, 103-112 (2012)

30. Janssen, A. et al. Time scales of associating food and odor by predator communities in the field. Behav. Ecol. 25, 1123-1130, https:// doi.org/10.1093/beheco/aru094 (2014).

31. Rim, H., Uefune, M., Ozawa, R., Yoneya, K. \& Takabayashi, J. Experience of plant infestation by the omnivorous arthropod Nesidiocoris tenuis affects its subsequent responses to prey-infested plant volatiles. BioControl 62, 233-242, https://doi.org/10.1007/ s10526-017-9791-2 (2017).

32. Glinwood, R., Ahmed, E., Qvarfordt, E. \& Ninkovic, V. Olfactory learning of plant genotypes by a polyphagous insect predator. Oecologia 166, 637-647, https://doi.org/10.1007/s00442-010-1892-x (2011).

33. Rim, H., Uefune, M., Ozawa, R. \& Takabayashi, J. Olfactory response of the omnivorous mirid bug Nesidiocoris tenuis to eggplants infested by prey: Specificity in prey developmental stages and prey species. Biol. Control 91, 47-54, https://doi.org/10.1016/j. biocontrol.2015.07.009 (2015).

34. Song, B. et al. Behavioral responses of Aphis citricola (Hemiptera: Aphididae) and its natural enemy Harmonia axyridis (Coleoptera: Coccinellidae) to non-host plant volatiles. Fla. Entomol. 100, 411-421, https://doi.org/10.1653/024.100.0202 (2017).

35. Drukker, B., Bruin, J., Jacobs, G., Kroon, A. \& Sabelis, M. W. How predatory mites learn to cope with variability in volatile plant signals in the environment of their herbivorous prey. Exp. Appl. Acarol. 24, 881-895, https://doi.org/10.1023/A:1010645720829 (2000).

36. Drukker, B., Bruin, J. \& Sabelis, M. W. Anthocorid predators learn to associate herbivore-induced plant volatiles with presence or absence of prey. Physiol. Entomol. 25, 260-265 (2000).

37. Jürgens, A. \& Bischoff, M. Changing odour landscapes: the effect of anthropogenic volatile pollutants on plant-pollinator olfactory communication. Funct. Ecol. 31, 56-64, https://doi.org/10.1111/1365-2435.12774 (2017).

38. Hilker, M. \& Schröder, R. The relevance of background odor in resource location by insects: A behavioral approach. Bioscience 58, 308-316, https://doi.org/10.1641/b580406 (2008).

39. Song, B. et al. Effects of intercropping with aromatic plants on the diversity and structure of an arthropod community in a pear orchard. BioControl 55, 741-751, https://doi.org/10.1007/s10526-010-9301-2 (2010).

40. Tang, G. B. et al. Repellent and attractive effects of herbs on insects in pear orchards intercropped with aromatic plants. Agrofor. Syst. 87, 273-285, https://doi.org/10.1007/s10457-012-9544-2 (2013).

41. Mutisya, S., Saidi, M., Opiyo, A., Ngouajio, M. \& Martin, T. Synergistic Effects of Agronet Covers and Companion Cropping on Reducing Whitefly Infestation and Improving Yield of Open Field-Grown Tomatoes. Agronomy 6, 42 (2016). 
42. Wan, H. H., Song, B. Z., Tang, G. B., Zhang, J. \& Yao, Y. C. What are the effects of aromatic plants and meteorological factors on Pseudococcus comstocki and its predators in pear orchards? Agrofor. Syst. 89, 537-547, https://doi.org/10.1007/s10457-015-9789-7 (2015).

43. Zhang, Z. et al. Effects of intercropping tea with aromatic plants on population dynamics of arthropods in Chinese tea plantations. J. Pest Sci. 90, 227-237, https://doi.org/10.1007/s10340-016-0783-2 (2017).

44. Bates, D., Maechler, M. \& Bolker, B. lme4: linear mixed-effects models using Eigen and S4. v. 1.1-7 (2014).

45. R Core Team. R: A language and environment for statistical computing v. 3.4.2 (R Foundation for Statistical Computing, Vienna, Austria, 2017).

46. Hothorn, T., Bretz, F. \& Westfall, P. Simultaneous inference in general parametric models. Biom. J. 50, 346-363, https://doi. $\operatorname{org} / 10.1002 / \mathrm{bimj} .200810425(2008)$.

\section{Acknowledgements}

This work was financially supported in part by MEXT Grants-in-Aid for Scientific Research on Innovative Areas to GA (18H04630 and 18H04786).

\section{Author contributions}

H.R. and G.A. conceived and designed research. H.R. and S.H. conducted experiments. H.R. analyzed data. H.R. and G.A. wrote the manuscript. All authors read and approved the manuscript.

\section{Competing interests}

The authors declare no competing interests.

\section{Additional information}

Supplementary information is available for this paper at https://doi.org/10.1038/s41598-020-58907-6.

Correspondence and requests for materials should be addressed to G.-i.A.

Reprints and permissions information is available at www.nature.com/reprints.

Publisher's note Springer Nature remains neutral with regard to jurisdictional claims in published maps and institutional affiliations.

(c) (i) Open Access This article is licensed under a Creative Commons Attribution 4.0 International License, which permits use, sharing, adaptation, distribution and reproduction in any medium or format, as long as you give appropriate credit to the original author(s) and the source, provide a link to the Creative Commons license, and indicate if changes were made. The images or other third party material in this article are included in the article's Creative Commons license, unless indicated otherwise in a credit line to the material. If material is not included in the article's Creative Commons license and your intended use is not permitted by statutory regulation or exceeds the permitted use, you will need to obtain permission directly from the copyright holder. To view a copy of this license, visit http://creativecommons.org/licenses/by/4.0/.

(c) The Author(s) 2020 